\section{Proportion Susceptible}

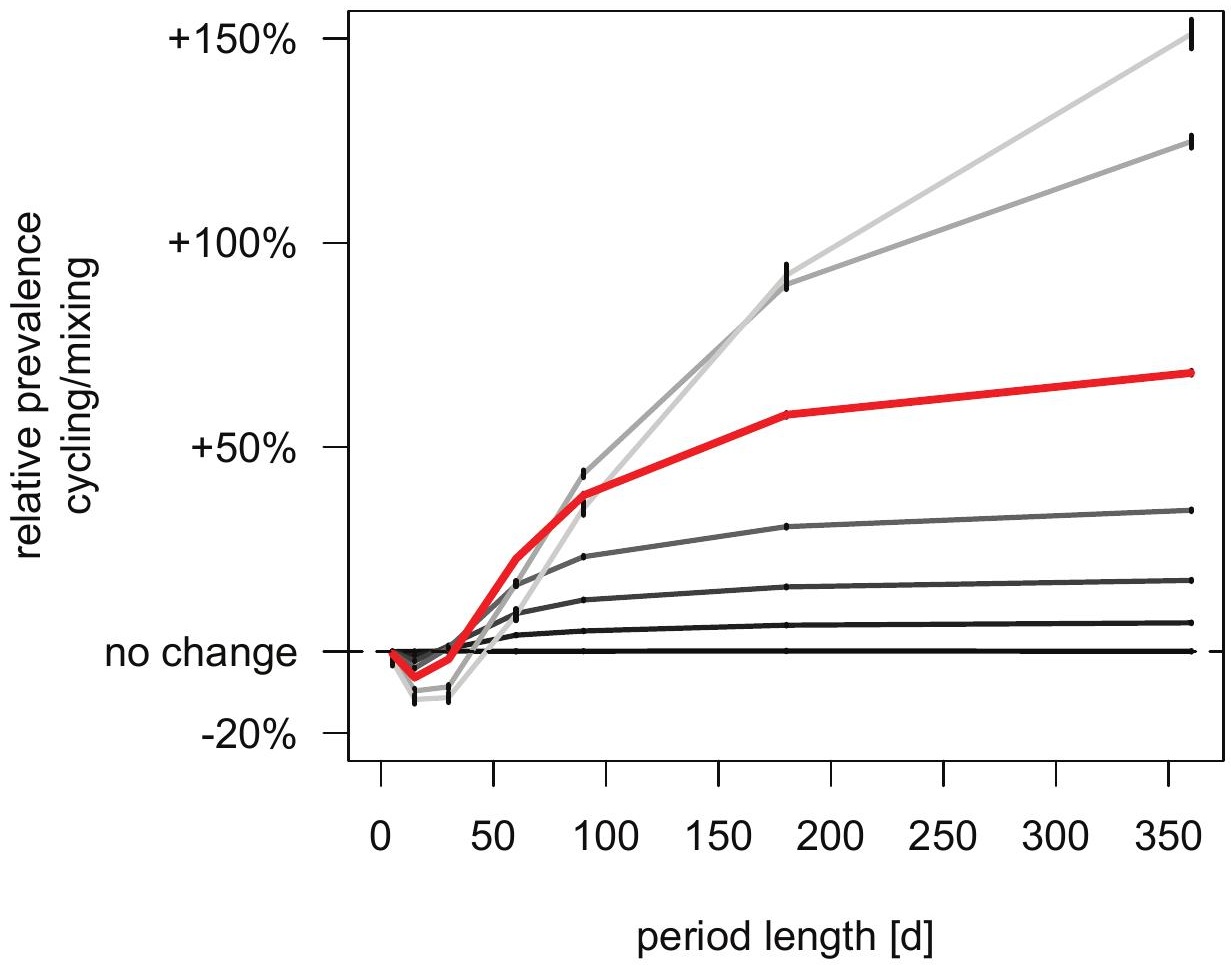

B

Environmental decay rate

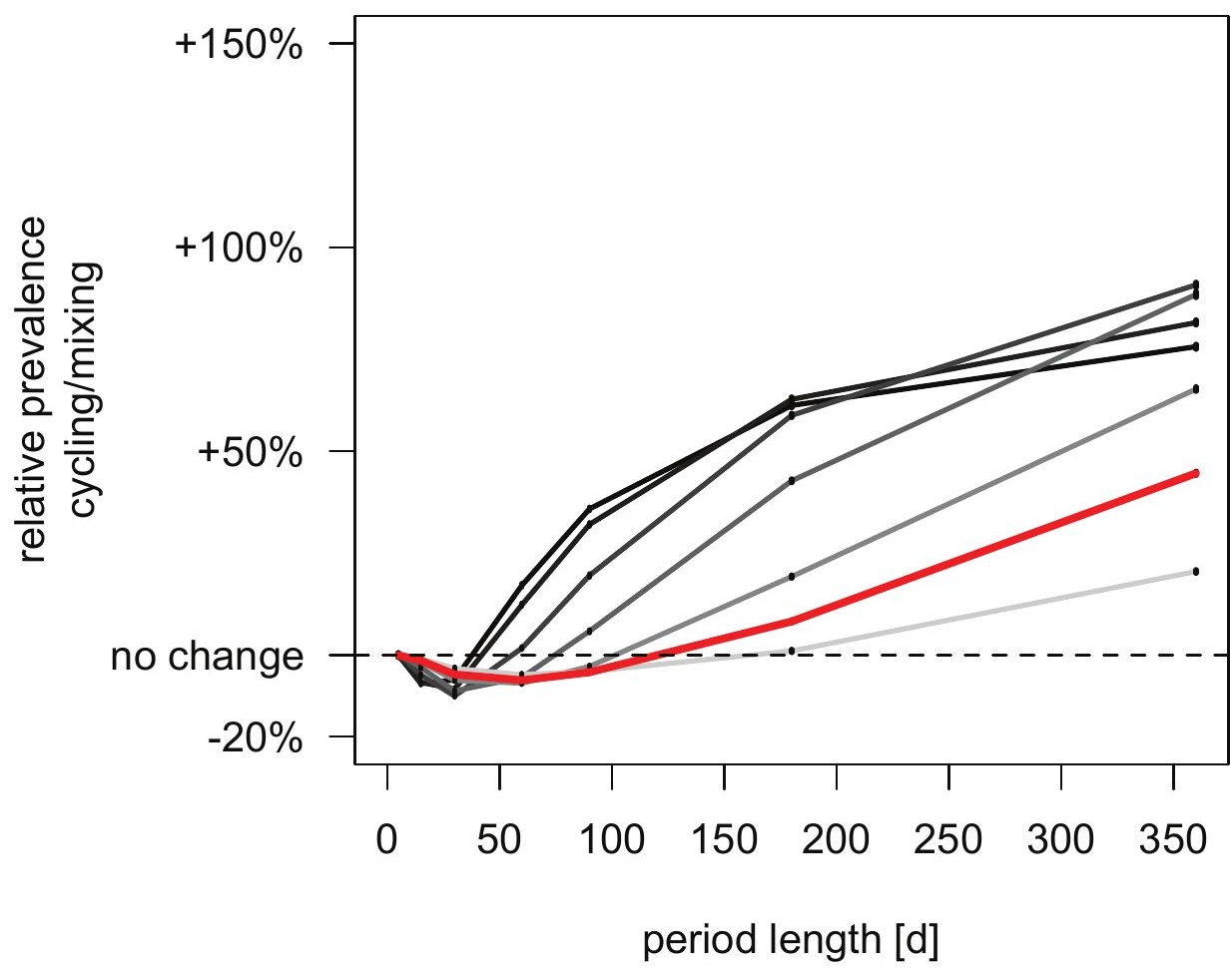

